\title{
Thrombosis and risk factors
}

\section{Tromboz ve risk faktörleri}

\author{
Nejat Akar \\ TOBB Economy and Technical University Hospital, Ankara, Turkey
}

\section{To the E ditor,}

I read the three papers related to thrombosis, appeared in the recent issue of the journal with great interest [1-3].

Yokus et al. described their patients with cerebral vein thrombosis and evaluated the risk factors for thrombosis. Especially they emphasize the MTHFR 677 C-T alteration. They stated that none of the MTHFR homozygote had high homocysteine levels. And also the two patients with high homocysteine levels did not have $677 \mathrm{~T}$ polymorphism [1]. Illhan et al's patient was heterozygous for $677 \mathrm{~T}$ with normal homocysteine level [2]. These reports indicated a very interesting point.

Yokus et al. stated that association between the MTHFR 677 T polymorphism and vascular disease is a matter of debate. Their data does not support the common view that TT genotype of MTHFR 677 CT is an influencing factor on homocysteine levels. Recently, we reported that MTHFR $677 \mathrm{~T}$ has an influence on homocysteine levels in our population but also we found another possible MTHFR 677 TT haplotype, which does not have an effect on homocysteine levels [4].

These reports and our data indicated a very important point. Only homocysteine levels should be routinely analyzed and not the MTHFR $677 \mathrm{~T}$ polymorphism.

Further, Uz et al. reported a patient with portal vein thrombosis (PVT) secondary to Klebsiella oxytoca bacteriemia [3]. They omitted Prothrombin 20210A mutation and FVIII levels of their patient. It was hypothesized that evaluation of these two risk factors in PVT is needed [5-8]. Although the patient is septic and FVIII may increase during infection, it would be an interesting finding. Moreover, although PT mutation is present mainly in cirrhotic patients [5] and not present in endemic areas of PVT like India $[9,10]$, it worth analyzing both risk factors in Turkish population with PVT.

\section{Conflict of Interest}

Author of this paper has no conflict of interest, including specific financial interests, relationships, and/or affiliations relevant to the subject matter or materials included in this manuscript.

\section{References}

1. Yokuş O, Balçık ÖŞ, Albayrak M, Ceran F, Dağdaş S, Yılmaz M,Özet G. Evaluation of risk factors for thrombophilia in patients with cerebral venous thrombosis. Turk $\mathrm{J}$ Hematol. 2010;27:162-7. 
2. Gül İlhan, Selami K. Toprak, Neslihan Andıç, Sema Karakuş. Idiopathic thrombocytopenic purpura with venous thrombosis: A case report. Turk J Hematol 2010;27:209-10.

3. Uz E, Alıcı Ö, Balçık ÖŞ, Kanbay M, Işık A, Uz B, Kaya A, Koşar A. Portal vein thrombosis secondary to Klebsiella oxytoca bacteriemia. Turk J Hematol 2010;27:213-5.

4. Koç YL, Akar N. Single nucleotide polymorphisms that affect homocysteine levels in Turkish population. Clin Appl Thromb Hemost. 2009;15:701-4.

5. Erkan O, Bozdayi AM, Disibeyaz S, Oguz D, Ozcan M, Bahar K, Karayalcin S, Ozden A, Bozkaya H, Yurdaydin C, Uzunalimoglu O. Thrombophilic gene mutations in cirrhotic patients with portal vein thrombosis. Eur J Gastroenterol Hepatol. 2005;3:339-43.

6. Hirmerova J, Liska V, Mirka H, Chudacek Z, Treska V. Portal and mesenteric vein thromboses in a patient with prothrombin G20210 mutation, elevated lipoprotein (a), and high factor VIII. Clin Appl Thromb Hemost. 2008;14:481-5.

7. Koshy A, Jeyakumari M. High FVIII level is associated with idiopathic portal vein thrombosis in South India. Am J Med. 2007; 120:552.e9-11.

8. Akar N. Idiopathic portal vein thrombosis and FVIII levels. Thromb Res. 2007;120:141.

9. Sharma S, Kumar SI, Poddar U, Yachha SK, Aggarwal R. Factor V Leiden and Prothrombin gene G20210A mutations are uncommon in portal vein thrombosis in India. Indian J Gastroenterol. 2006;25:236-9.

10. Koshy A, Jeyakumari M. Prothrombin G20210A gene variant is not associated with idiopathic portal vein thrombosis in an area endemic for portal vein thrombosis. Ann Hematol. 2006;85:126-8. 